\title{
Potential of calcium silicate to mitigate water deficiency in maize
}

\author{
Douglas José Marques ${ }^{1}$, Mozart Martins Ferreira², Allan Klynger da Silva Lobato ${ }^{3}$, Wellington Alves \\ de Freitas² ${ }^{2}$ Jacinto de Assunção Carvalho², Ewerton Dilelis Ferreira ${ }^{3}$, Fernando Broetto ${ }^{4 *}$ \\ 1. Universidade José do Rosário Vellano - Faculdade de Agronomia - Alfenas (MG), Brazil. \\ 2. Universidade Federal de Lavras - Departamento de Ciência do Solo - Lavras (MG), Brazil. \\ 3. Universidade Federal Rural da Amazônia - Instituto de Ciências Agrárias - Paragominas (PA), Brazil. \\ 4. Universidade Estadual Paulista “Júlio de Mesquita Filho" - Instituto de Biociências - Departamento de Química e \\ Bioquímica - Botucatu (SP), Brazil.
}

\begin{abstract}
The aim of this study was to evaluate the potential of calcium silicate to mitigate the effects of water deficiency in maize plants yield. A completely randomized factorial design, consisting of five combinations of calcium silicate $(0,25,50,75$, and $100 \%)$ and five different soil moisture levels (30,70,100,130, and 160\%), was adopted. The following parameters were evaluated: soil matric potential, xylem water potential, silicon concentration, leaf dry weight, and dry mass production. Matric potential monitoring confirmed that the irrigation
\end{abstract}

depths employed resulted in different environments for maize plant development during the experiment. Confirming the hypothesis of the study, at the lower irrigation depths, the maize production has accompanied the increase in calcium silicate used as corrective up to the proportion of $50 \%$. These results indicate that silicon mitigated the impact of water deficiency in maize plants and increased the xylem water potential.

Key words: Dry matter, irrigation, silicon, stress.

\section{INTRODUCTION}

The world population is increasing, especially in the poorest and most vulnerable countries of the Third World, where food production is insufficient to maintain this growing population because they live in marginal agricultural areas characterized by water and nutrient deficiency (Giehl and Wirén 2014; Rockström and Falkenmark 2000). The development of strategies to reduce water stress in arid and semiarid regions is a sustainable alternative to mitigate the negative impacts of global climate changes. In view of the complexity of drought stress, only an approach that will consider soil-plant-environment interactions may generate relevant knowledge that can be used in the near future to guarantee sustainability. The conditions for the development of maize crops were unfavorable throughout Brazil in 2013, since the rain recorded during crop cycle period was not sufficient to replenish soil moisture levels. Furthermore, temperatures continued to be high, a fact which contributed to the maintenance of high rates of evapotranspiration. As a consequence, many maize fields in 2013 are already under the effect of water stress, reducing the crop yield potential (Boletim Agrometeorológico Semanal 2014).

The scarcity of water resources in conjunction with global warming has exerted negative effects on the planet's agricultural activity over the last ten years (IBGE 2010). In this respect, lines of research focusing on the understanding, behavior and improvement of cultivated species in response to inadequate environmental situations have captured substantial resources and gained more visibility (Stenseth 2002). The increase in temperature due to global warming may cause losses in maize grain yields of R $\$ 7.4$ billion already in 2020 - a number that could rise to $\mathrm{R} \$ 14$ billion in 2070 . The most pessimistic predictions estimate a temperature increase of 2 to $5.4^{\circ} \mathrm{C}$ until 2100, and the most optimistic ones estimate an increase of 1.4 to $3.8^{\circ} \mathrm{C}$ until 2100 (Assad and Pinto 2008). 
In Brazil, about $20 \%$ of the maize planted area, corresponding to approximately 8.5 million hectares, is affected by drought, resulting in a production loss of these crops of more than 23.7 million tons. In specific years and places, drought may even lead to total production loss (Durães et al. 2002).

In order to mitigate the effects of abiotic and biotic stress, silicon exerts several specific functions (Moro et al. 2015), and its absorption by plants has several benefits, protecting against saline stress, metal toxicity, water deficit, radiation damage, high temperature and frost and regulating nutrient balance. These beneficial effects are attributed to the high accumulation of silica in plant tissues (Ma 2004). The mechanisms used by plants in situations of stress include the activity of enzymes involved in the protection against oxidative stress, such as catalase, superoxide dismutase, peroxidases, and glutathione.

The aim of the present study was to evaluate the effect of calcium silicate as an option to mitigate water stress in maize crops.

\section{MATERIAL AND METHODS}

The experiment was carried out at the Department of Soil Science of the Federal University of Lavras, Minas Gerais, Brazil (lat $21^{\circ} 14^{\prime} \mathrm{S}$; long $45^{\circ} 00^{\prime} \mathrm{W}$; 915 masl), under greenhouse conditions. Seeds of Zea mays L. (cv. BR 106) were used, which are adapted to the conditions of Brazil, characterized by a plant height of $2.4 \mathrm{~m}$, ear length of $0.16 \mathrm{~m}$, and yield of $5.5 \mathrm{t} \cdot \mathrm{ha}^{-1}$ (Embrapa 2013). The soil of the region is classified as Red Latosol-Oxisol (Embrapa 2006).For soil physico-chemical characterization (Table 1), the following proprieties were determined: $\mathrm{pH}$ in water (1:2.5), $\mathrm{P}$ and $\mathrm{K}$ by Mehlich-1 extraction, $\mathrm{Mg}$ and $\mathrm{Al}$ extractable by $1 \mathrm{M} \mathrm{KCl}$ solution, $\mathrm{P}$ in the equilibrium solution according to Álvarez et al. (2000), and level of organic matter according to Anne (1945). The soil granulometry was determined by the pipette method. A completely randomized factorial design consisting of five corrective combinations $(0,25,50,75$, and $100 \%$ of calcium silicate indicated for liming of this soil) and five different soil moisture conditions $(30,70,100,130$, and $160 \%$ of amount necessary for water replenishment in this soil), with four repetitions, was used. The volume of each pot was $15 \mathrm{~L}$.

Table 2 shows the amounts of calcium silicate $\left(\mathrm{CaSiO}_{3}\right)$ and calcium carbonate $\left(\mathrm{CaCO}_{3}\right)$ present in the different combinations. Additionally, calcium was applied in the form of calcium chloride $\left(\mathrm{CaCl}_{2}\right)$ to balance the amount of this element in the treatments. After treatment application, the soil was incubated for 45 days. Macro and micronutrient fertilization (Table 3) was carried out as described by Novais et al. (1991). The Chemical composition of the soil after the corrective associations is summarized in Table 4.

The water retention curve (Figure 1) was used to water characterization of the soil, and data were applied in the formulas $\theta=0.4215 \times\left[1+\left(0.2040 \times\left|\Psi_{m}\right|\right)^{1.8757}\right]^{-0.4669}+0.2670$ and $\Psi_{m}=[1 / \alpha(1 / m) 1 / n]$, in agreement with van Genuchten (1980), where $\theta$ is the humidity current $\left(\mathrm{cm}^{3} \cdot \mathrm{cm}^{-3}\right), \Psi_{m}$ is the tension in soil $(\mathrm{kPa}), \alpha, m$, and $n$ are parameters linked to equation adjustment in the model proposed by van Genuchten.

The field capacity was estimated by equation $\theta_{i}=\left(\theta_{s}-\theta_{r}\right) \times[1+1 / m]^{-m}+\theta_{r}$, as proposed by Dexter (2004), where $\theta_{i}$ is the humidity in inflexion point of the curve $\left(\mathrm{cm}^{3} \cdot \mathrm{cm}^{-3}\right), \theta_{s}$ is the humidity of saturation $\left(\mathrm{cm}^{3} \cdot \mathrm{cm}^{-3}\right)$, and $\theta_{r}$ is the humidity residual $\left(\mathrm{cm}^{3} \cdot \mathrm{cm}^{-3}\right)$. The value of humidity calculated in field capacity of this study was $0.3458 \mathrm{~cm}^{3} \cdot \mathrm{cm}^{-3}$ to tension of $-40 \mathrm{kPa}$.

Table 1. Chemical and physical compositions of the soil used in this study.

\begin{tabular}{|c|c|c|c|c|c|c|c|c|c|c|c|c|c|c|c|c|c|}
\hline \multicolumn{18}{|c|}{ Chemical } \\
\hline $\mathbf{p H}$ & \multicolumn{3}{|c|}{$\left(\mathrm{mg} \cdot \mathrm{dm}^{-3}\right)$} & \multicolumn{6}{|c|}{$\left(\mathbf{m g} \cdot \mathrm{L}^{-1}\right)$} & \multicolumn{5}{|c|}{$\left(\right.$ mmolc $\left.\cdot \mathrm{dm}^{-3}\right)$} & \multicolumn{3}{|c|}{$(\%)$} \\
\hline 5.0 & 53.7 & 20.0 & 2.7 & 0.6 & 1.3 & 17.7 & 6.7 & 0.1 & 31.1 & 36.3 & 1.5 & 0.4 & 0.5 & 3.6 & 5.6 & 20.4 & 35.1 \\
\hline \multicolumn{18}{|c|}{ Physical } \\
\hline \multicolumn{4}{|c|}{ Sand (\%) } & \multicolumn{6}{|c|}{ Silt (\%) } & \multicolumn{4}{|c|}{ Clay (\%) } & \multicolumn{4}{|c|}{ OM $\left(\right.$ dag $\left.\cdot k^{-1}\right)$} \\
\hline \multicolumn{4}{|c|}{38} & \multicolumn{6}{|c|}{13} & \multicolumn{4}{|c|}{49} & \multicolumn{4}{|c|}{2.1} \\
\hline
\end{tabular}

pH in water (1:2.5), P and K by Mehlich-1 (Bortolon and Gianello 2010) extraction, Mg and Al extractable by $1 \mathrm{M} \mathrm{KCl}$ solution (Thomas 1982); P in the equilibrium solution (EP) according to Álvarez et al. (2000); level of organic matter (OM) according to Anne (1945). The soil granulometry was determined by the pipette method (Day 1965). $\mathrm{T}=$ Cation exchange capacity at pH 7.0; $\mathrm{m}=$ Aluminum saturation index; $\mathrm{V}=$ Base saturation index (Olsen and Watanabe 1957). 
Table 2. Amounts of $\mathrm{CaSiO}_{3}, \mathrm{CaCO}_{3}$, and $\mathrm{CaCl}_{2}$ used in different associations.

\begin{tabular}{|c|c|c|c|}
\hline Association (\%) & $\mathrm{CaSiO}_{3}\left(\mathrm{~g} \cdot \mathrm{pot}^{-1}\right)$ & $\mathrm{CaCO}_{3}\left(\mathrm{~g} \cdot \mathrm{pot}^{-1}\right)$ & $\mathrm{CaCl}_{2}\left(\mathrm{~g} \cdot \mathrm{pot}^{-1}\right)$ \\
\hline 100 & 12.20 & 0.00 & 0.00 \\
\hline 75 & 9.15 & 2.63 & 1.03 \\
\hline 50 & 6.10 & 5.25 & 2.06 \\
\hline 25 & 3.05 & 7.88 & 3.09 \\
\hline 0 & 0.00 & 10.50 & 4.12 \\
\hline
\end{tabular}

Table 3. Nutrients, recommended amounts, and sources used in fertilization in this study.

\begin{tabular}{ccc}
\hline Nutrient & Concentration (mg kg per soil) & Source \\
\hline $\mathrm{N}$ & 300 & $\mathrm{NH}_{4} \mathrm{H}_{2} \mathrm{PO}_{4}$ \\
\hline $\mathrm{P}$ & 300 & $\mathrm{KH}_{2} \mathrm{PO}_{4}$ \\
\hline $\mathrm{K}$ & 200 & $\mathrm{KH}_{2} \mathrm{PO}_{4}$ \\
\hline $\mathrm{S}$ & 40 & $\mathrm{~K}_{2} \mathrm{SO}_{4}$ \\
\hline $\mathrm{Mg}$ & 46 & $\mathrm{MgSO}_{4} \cdot 7 \mathrm{H}_{2} \mathrm{O}$ \\
\hline $\mathrm{B}$ & 2.5 & $\mathrm{H}_{3} \mathrm{BO}_{3}$ \\
\hline $\mathrm{Cu}$ & 7.5 & $\mathrm{CuSO}_{4} \cdot 5 \mathrm{H}_{2} \mathrm{O}$ \\
\hline $\mathrm{Mo}$ & 0.5 & $\left(\mathrm{NH}_{4}\right)_{6} \mathrm{MO}_{7} \mathrm{O}_{24} \cdot 4 \mathrm{H}_{2} \mathrm{O}$ \\
\hline $\mathrm{Zn}$ & 2.5 & $\mathrm{ZnSO}_{4} \cdot 7 \mathrm{H}_{2} \mathrm{O}$
\end{tabular}

Table 4. Chemical composition of the soil after the corrective associations.

\begin{tabular}{|c|c|c|c|c|c|c|c|c|c|c|c|c|c|}
\hline \multicolumn{2}{|c|}{$\begin{array}{c}\text { Corrective } \\
\text { associations }\end{array}$} & \multicolumn{12}{|c|}{ Measurements } \\
\hline $\begin{array}{r}\mathrm{CaSiO}_{3} \\
\left({ }^{\circ}\right.\end{array}$ & (\%) & pH & $\begin{array}{l}P \\
\text { (mg }\end{array}$ & $\begin{array}{r}K \\
\left.n^{-3}\right)\end{array}$ & $\left(\mathrm{mg} \cdot \mathrm{L}^{-1}\right)$ & Ca & Mg & $\begin{array}{l}\text { Al } \\
\text { olc.c }\end{array}$ & $\begin{array}{l}\mathbf{H}+\mathbf{A l} \\
-3)\end{array}$ & $\mathbf{T}$ & $\begin{array}{c}m \\
(\%)\end{array}$ & $\mathbf{v}$ & $\begin{array}{c}\text { OM } \\
\left(\text { dag }^{\prime} \mathbf{k g}^{-1}\right)\end{array}$ \\
\hline 100 & 0 & 5.3 & 118.1 & 139 & 27.3 & 3.5 & 1.1 & 0.1 & 3.6 & 8.6 & 2.0 & 57.8 & 2.6 \\
\hline 75 & 25 & 5.2 & 114.7 & 122 & 34.1 & 3.5 & 1.1 & 0.1 & 3.6 & 8.6 & 2.0 & 57.8 & 2.6 \\
\hline 50 & 50 & 5.1 & 143.6 & 131 & 38.3 & 3.2 & 1.2 & 0.1 & 3.6 & 8.4 & 2.1 & 56.8 & 2.6 \\
\hline 25 & 75 & 5.3 & 125.0 & 109 & 39.4 & 2.9 & 1.0 & 0.1 & 3.6 & 7.8 & 2.4 & 53.4 & 2.6 \\
\hline 0 & 100 & 5.2 & 121.5 & 150 & 37.2 & 2.5 & 1.0 & 0.1 & 4.0 & 8.0 & 2.5 & 49.4 & 2.6 \\
\hline
\end{tabular}

pH in water (1:2.5), P and K by Mehlich-1 (Bortolon and Gianello 2010) extraction, Mg and Al extractable by $1 \mathrm{M} \mathrm{KCl}$ solution (Thomas 1982); P in the equilibrium solution (EP) according to Álvarez et al. (2000); level of organic matter (OM) according to Anne (1945). The soil granulometry was determined by the pipette method (Day 1965). $T$ = Cation exchange capacity at pH 7.0; $\mathrm{m}$ = Aluminum saturation index; $\mathrm{V}=$ Base saturation index (Olsen and Watanabe 1957).

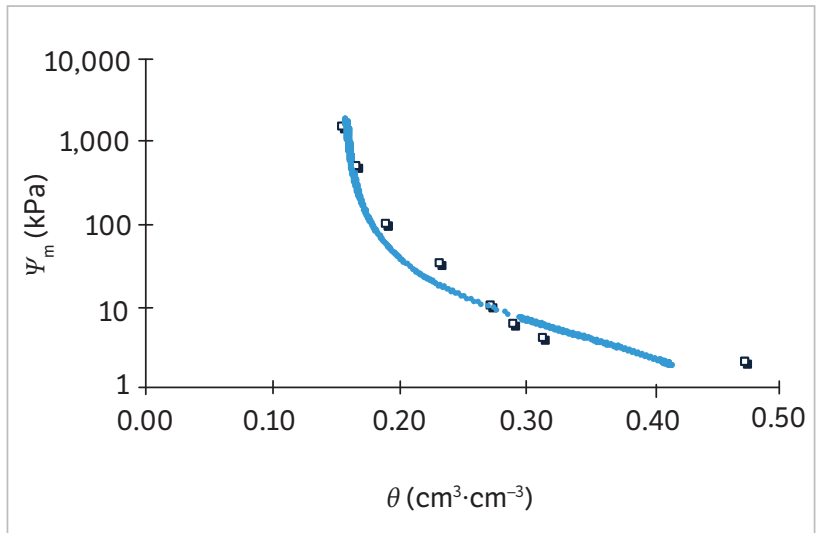

Figure 1. Water retention curve for Red Latosol used in the experiment. $\theta=$ volumetric water content $\left(\mathrm{cm}^{3} \cdot \mathrm{cm}^{-3}\right)$.
The soil was irrigated when the soil water tension reached a value of $-40 \mathrm{kPa}$ at each irrigation depth $(30,70,100,130$, and $160 \%$ of the depth necessary for water replenishment in this soil). All measurements were made daily at 5:00 PM, and soil moisture meters (Watermark, model 200SS-5) were installed to quantify the matric potential (Figure 1) only at the three highest tensions (30, 70, and $100 \%$ of ideal depth). The water volume necessary for irrigation was calculated by the equation: $V=\left(\theta_{f c}-\theta_{\text {treat }}\right) \times V_{\text {soil }}$, where $V$ is the water volume to be applied (mL), $\theta_{f_{c}}$ is the water content at field capacity $\left(\mathrm{cm}^{3} \cdot \mathrm{cm}^{-3}\right), \theta_{\text {treat }}$ is the water content in the treatment $\left(\mathrm{cm}^{3} \cdot \mathrm{cm}^{-3}\right)$, and $V_{\text {soil }}$ is the soil volume $(\mathrm{mL})$. 
The electrical conductivity (EC) of the saturated paste extract was determined as described by Richards (1954). Dry mass was determined by drying the leaves of maize plants in an oven with ventilation at $60^{\circ} \mathrm{C}$ until a constant mass was obtained. The xylem water potential $\left(\Psi_{w}\right)$ was measured in fully expanded leaves under light between 5:00 and 6:30 AM and between 1:00 and 2:00 PM, corresponding to the predawn and midday potential, respectively. The water potential was measured with an analogue plant moisture system (Skye Instruments, model SKPM 1405/50), which is based on technical pressure chamber (Scholander et al. 1964), according to the procedure by Turner (1988).

Data were subjected to analysis of variance. When significant differences were observed, the Scott-Knott test was applied at a $\mathrm{p}>0.05$ level of error probability (Steel et al. 2006). Standard errors were calculated for all means. All statistical procedures were carried out using the SAS software (SAS Institute 1996).

\section{RESULTS AND DISCUSSION}

Figure 2 illustrates the soil matric potential data before and after irrigation corresponding to 30\% (Figure 2a), 70\% (Figure $2 \mathrm{~b}$ ) and $100 \%$ (Figure 2c) of the recommended irrigation depth, while Figure $2 \mathrm{~d}$ shows the matric potential readings obtained with the Watermark sensor for irrigations corresponding to 30 and $70 \%$ of the recommended depth (Figures 2a,b) and the tensiometer (100\% of the recommended irrigation depth). Before irrigation, the highest readings of soil water tension were obtained for the treatment applying $30 \%$ of the recommended irrigation depth (Figure 2a), ranging from -90 to $-160 \mathrm{kPa}$. The tension readings ranged from -40 to $-130 \mathrm{kPA}$ for the application of $70 \%$ (Figure $2 \mathrm{~b}$ ) and from -25 to $-50 \mathrm{kPA}$ for the application of $100 \%$ (Figure $2 \mathrm{c}$ ). The tension gradient showed the same trend after irrigation; however, when $100 \%$ of the recommended irrigation depth was applied, the soil
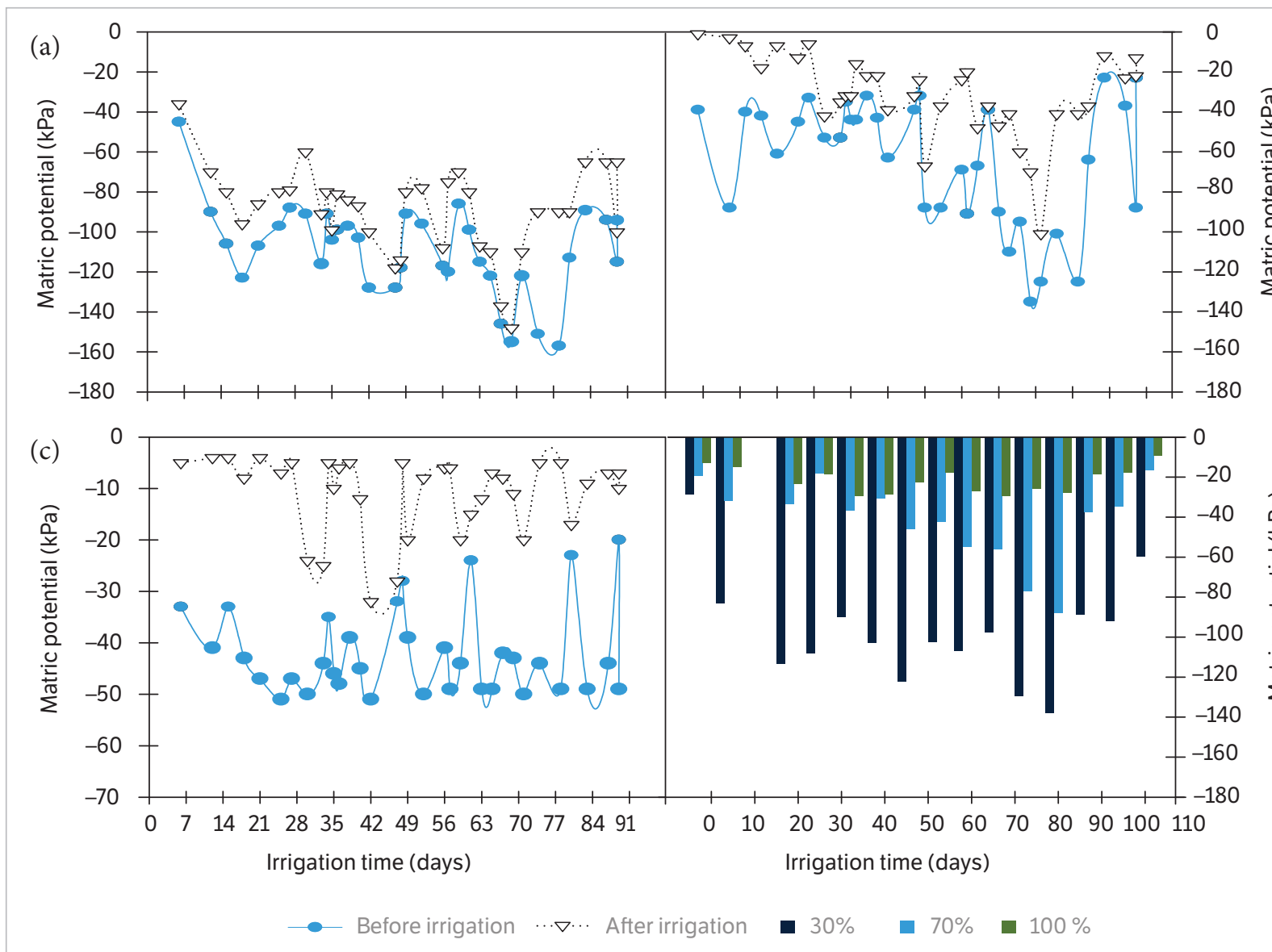

(d)

Figure 2. Matric potential of soil water before and after using it for irrigation depth of $30 \%$ (a), $70 \%$ (b), $100 \%$ (c) and monitoring of the matric potential of soil water using the Watermark sensor for the depth irrigation (30 and 70\%) and the depth considered ideal for tensiometer $(100 \%)(d)$. 
water tension remained in the range of -5 to $-30 \mathrm{kPa}$, a value lower than the tension at field capacity $(-40 \mathrm{kPa})$, i.e. the amount of water applied at this depth increased soil moisture to a level above its field capacity. As can be seen in Figure 2d, soil water tension varied according to the amount of water applied. The highest tension readings were obtained when $30 \%$ of the recommended irrigation depth was applied, followed by 70 and $100 \%$ of the recommended depth. The study of Resende et al. (2008) serves as a reference of the water conditions prevailing in the study area, which showed a potential of $-70 \mathrm{kPa}$ in Brazilian Cerrado under summer conditions and in the semiarid region at any time of the year, and of $-300 \mathrm{kPa}$ during the winter. It appears, therefore, as it was the objective of the present study, that water application corresponding to 30 and $70 \%$ of the recommended irrigation depth induced water deficit conditions. This deficit was much more pronounced when only $30 \%$ of the recommended depth was applied.

The variation in electrical conductivity as a function of the interaction between irrigation depth and proportion of calcium silicate is shown in Figure 3. Electrical conductivity tended to decrease as the amount of water applied increased, irrespective of the proportion of calcium silicate. The highest EC values were observed with the application of $30 \%$ of the recommended depth, followed by a reduction to half when $70 \%$ of the recommended depth was applied. The lowest values were observed with the application of $130 \%$. These results show that the smaller irrigation depth seems to increase the concentration of salts in soil, with a consequent increase in the osmotic potential of the soil solution. Soil salinization can result in nutritional disorders, inducing antagonistic relationships between nutrients in the plant, which significantly reduces crop yields (Grattan and Grieve 1999). These interactions can also occur between nutrients in the soil solution, affecting nutrient availability. Such interactions include antagonism, competitive and noncompetitive inhibition and synergism, events that can change the dynamics between cations in the leaves and roots of plants. Cuartero and Fernández-Muñoz (1998) observed a reduction in the dry mass of tomato stems, leaves and roots under conditions of salinity. The high concentration of ions in soil can lead to an imbalance in the water and ion potential at the soil-plant interface and can be toxic to the plant, thus affecting its growth and phytomass production (Asch et al. 2000) due to the

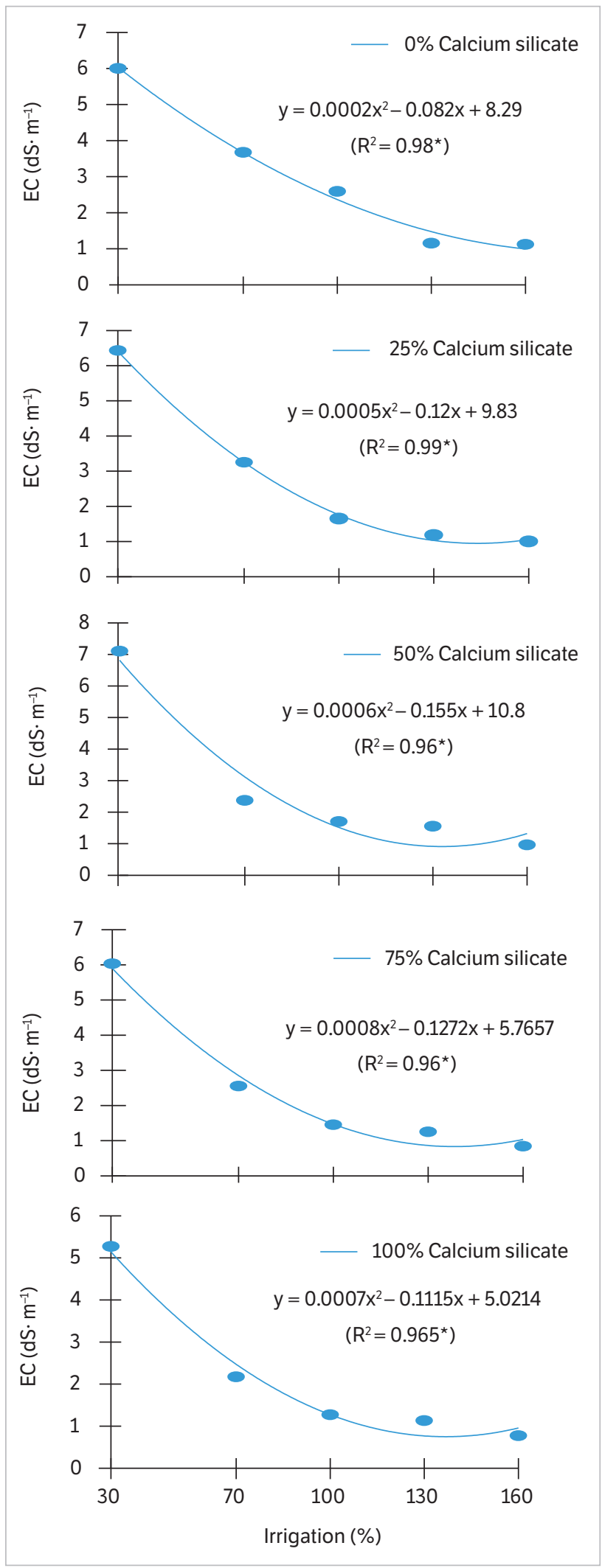

Figure 3. Soil solution electrical conductivity (EC) as a function of different irrigations in each proportion of calcium silicate. 
reduction in the absorption of mineral nutrients such as potassium, calcium and manganese (Lutts et al. 1999).

Figure 4 shows the xylem matric potential $\left(\Psi_{w}\right)$ of maize leaves at 30 ( $a$ and b) and 75 ( $c$ and d) days after planting according to the different proportions of calcium silicate and irrigation depths. At 30 and 70\% of the recommended irrigation depth (Figure 4a), pure calcium silicate was superior than other proportions tested. However, when irrigation was increased to 100,130 and $160 \%$ of the recommended depth, the proportion of $50 \%$ calcium silicate was superior for readings performed between 5:00 and 6:30 AM. In contrast, for readings performed between 1:00 and 2:00 PM, treatment with pure $(100 \%)$ calcium silicate was superior at 30,70 and $130 \%$ of the recommended irrigation depth, while $0 \%$ calcium silicate provided superior results only at $100 \%$ of the recommended depth (Figure $4 \mathrm{~b}$ ). At 75 days after planting (Figure $4 \mathrm{c}$ ), in the morning (5:00 to 6:30 AM), pure calcium silicate (100\%) was superior for application of 30 and $70 \%$ of the recommended irrigation depth. These depths are considered to be limiting. However, when irrigation was increased to 100,130 and $160 \%$, the application of $0 \%$ calcium silicate was superior compared to the other irrigation depths. Regarding $\Psi_{w}$, determined between 1:00 and 2:00 PM (Figure 4d), for application of $30 \%$ of the recommended irrigation depth, the calcium silicate proportion of $50 \%$ provided the highest $\Psi_{w}$ compared to the other proportions for the same treatment. However, when the irrigation depth was increased proportionally, the application of pure calcium silicate $(100 \%)$ was superior to the other proportions tested. In the presence of a water deficit, the plants use drought tolerance mechanisms such as osmotic adjustment, in which the cell absorbs water and maintains the pressure potential at adequate levels. The reduction in the osmotic potential in response to water deficit may

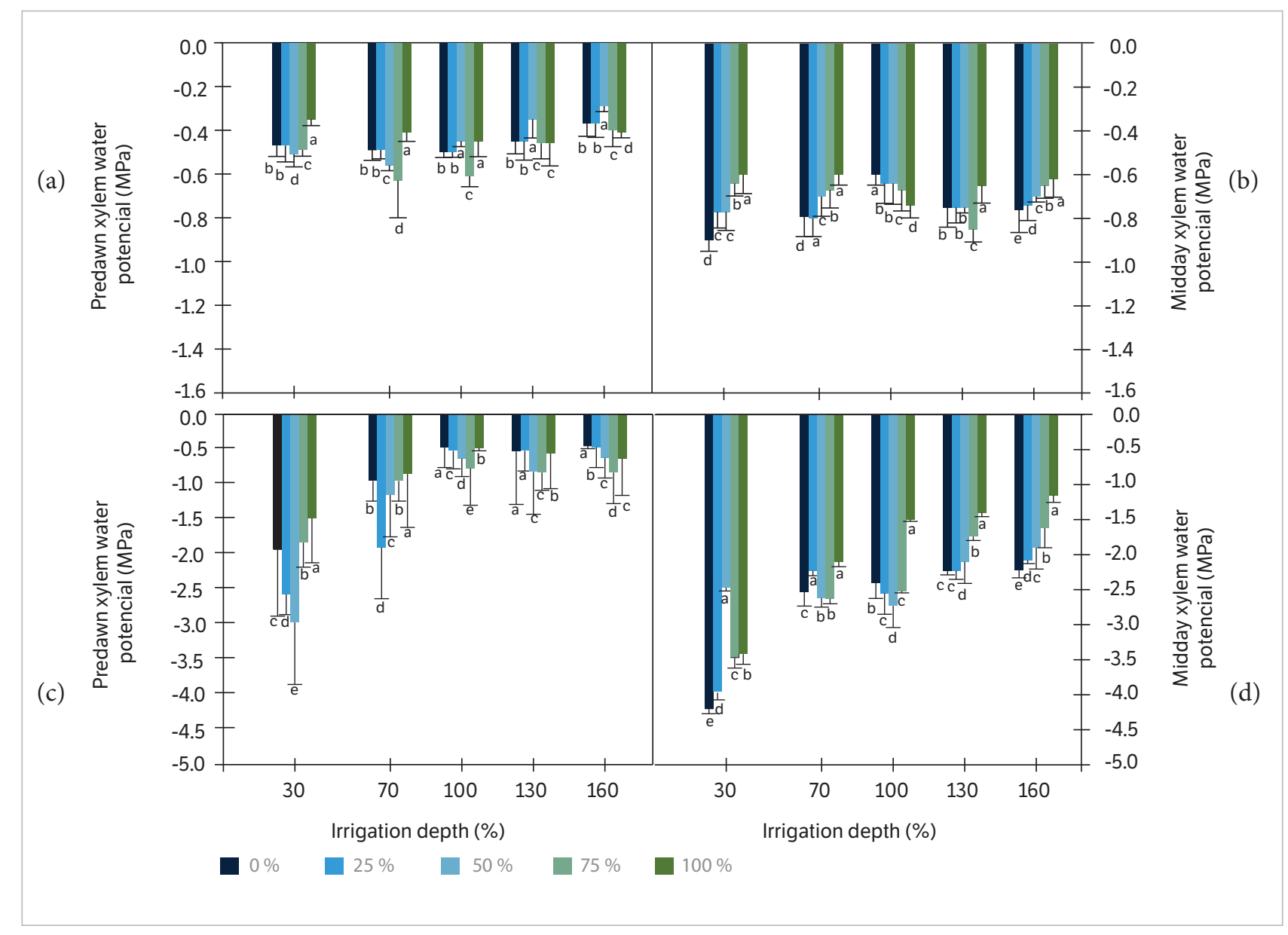

Figure 4. Xylem water potential $\left(\psi_{w}\right)$ in Zea mays (cv. 106 BR) 30 ( $a$ and b) and 75 (c and d) days after planting, depending on irrigation, in different proportions $(0,25,50,75$, and $100 \%)$ of calcium silicate. 
be the result of the passive accumulation of solutes as a consequence of dehydration of the cell or of active accumulation of solutes; however, only the latter can be considered osmotic adjustment (Patakas et al. 2002). Approximate leaf $\Psi_{w}$ values of $-0.5 \mathrm{MPa}$ are considered to be adequate for good development of maize and sorghum, while a value of $-0.8 \mathrm{MPa}$ inhibits photosynthesis and leaf growth and $-1.5 \mathrm{MPa}$ is the wilting point (Salah and Tardieu 1997; Klar and Porto 1998). About $95 \%$ of the water absorbed by the plant is used to maintain the thermal balance through transpiration.

Figure 5 illustrates the trend in leaf dry mass production as a function of increasing irrigation depth for each calcium silicate proportion. As can be seen, leaf dry mass increased with increasing amount of water applied at the different irrigation depths, irrespective of the proportion of calcium silicate. The trend in dry mass production according to irrigation depth at all proportions of calcium silicate can be described by quadratic functions. Leaf dry mass reaches maximum values with the application of $130 \%$ of the recommended depth and tends to decline thereafter. According to Malavolta et al. (1997), water stress reduces leaf dry mass production and crop yield. This reduction depends on the extent to which the water deficit has affected the areas of photosynthetic activity and on the rate and degree of recovery after the cessation of water stress. Considering the water stress conditions induced by the irrigation depths of 30 and $70 \%$, the calcium silicate proportions of 50,75 and $100 \%$ promoted the highest production of leaf dry mass. These data are important since they emphasize the benefit of silicon in mitigating water stress in maize crops. The use of the silicate-lime combination, notably the proportion of $50 \%$, demonstrated the complementarity of these correctives, since calcium silicate has a lower neutralization power than lime, which is more soluble.

Plant species vary in their capacity to absorb and accumulate silicon in tissues and can be classified according to the percentage of $\mathrm{SiO}_{2}$ in dry matter: (a) accumulator plants containing more than $4 \% \mathrm{SiO}_{2}$, which includes many grasses such as rice; (b) intermediate plants with an $\mathrm{SiO}_{2}$ content ranging from $2-4 \%$ (cereals, sugarcane, and few dicotyledons); (c) non-accumulator plants containing less than $2 \% \mathrm{SiO}_{2}$, which includes most dicotyledons such as beans (Ma and Takahashi 2002; Hodson et al. 2005). These differences in silicon
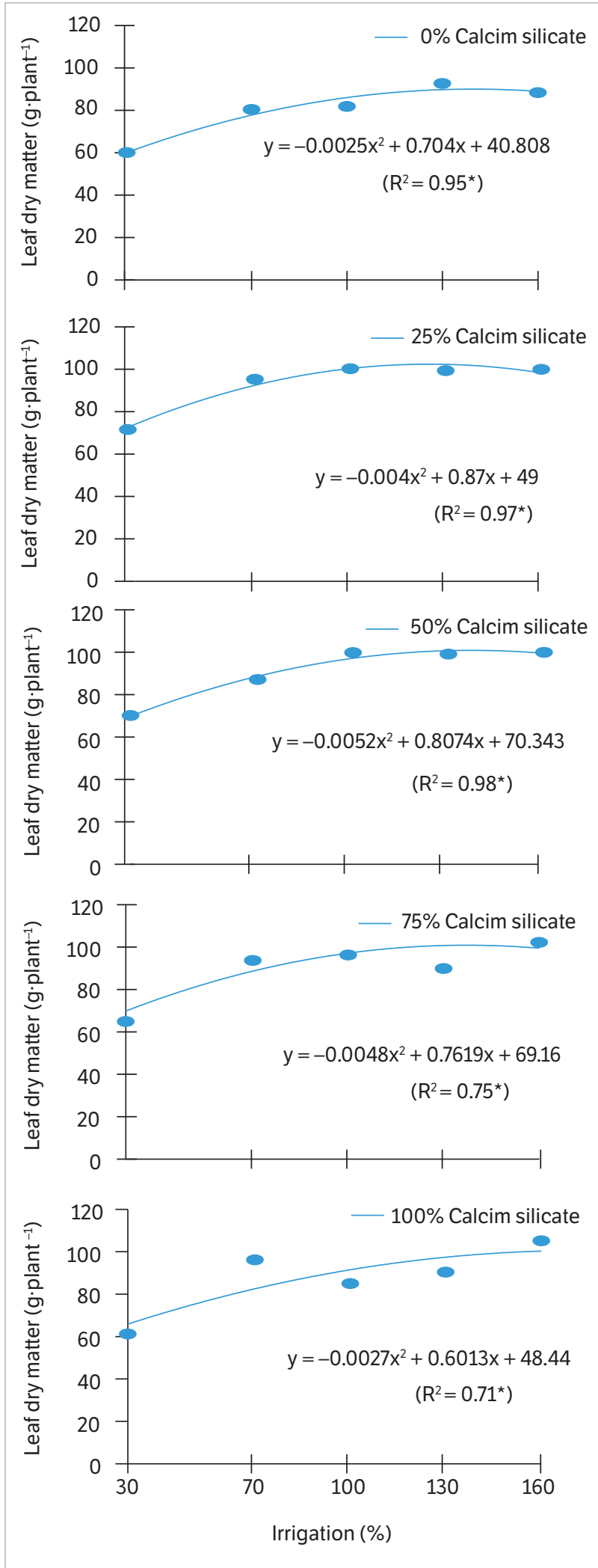

Figure 5. Leaf dry weight of maize plants (cv. BR 106), depending on irrigation, in different proportions $(0,25,50,75$, and $100 \%)$ of calcium silicate. 
accumulation have been attributed to the ability of roots to absorb this nutrient (Takahashi et al. 1990), but the exact mechanism is not fully understood. Figure 6 shows the concentrations of silicon in the stem (a), leaf (b), ear husks (c), cob (d) and grains (e) of maize according to the proportion of calcium silicate for each irrigation depth. In general, Si concentrations in the leaf and ear increased with increasing irrigation depth, irrespective of the proportion of calcium silicate. In the stem, cob and grains, Si concentrations did not vary between the irrigation depths used. The different proportions of calcium silicate in the corrective did not affect Si concentrations in maize stem, cob or grains. Most intriguingly, the highest $\mathrm{Si}$ concentrations were observed in the stem at $30 \%$ of the recommended irrigation depth, in cobs at $130 \%$ of the recommended depth and in grains in the absence of silicate in the corrective. On the other hand, the presence of calcium silicate in the corrective had positive effects on $\mathrm{Si}$ concentrations in leaves and ears. At all irrigation depths, Si concentrations were associated with higher proportions of calcium silicate. The greater $\Psi_{w}$ (Figure 4) of maize leaves may explain the higher silicon content of leaves which increases the efficiency of gas exchanges. These results agree with those of Hashemi et al. (2010), who suggested Si to be an element that confers greater resistance to biotic and abiotic stress in plants.

Figure 7 compares grain production between the different proportions of calcium silicate according to irrigation depth. As a general trend, production increased with increasing irrigation depth. At $30 \%$ of the recommended irrigation depth, higher production was observed for calcium silicate proportions of 50,75 and $100 \%$. In contrast, at $70 \%$ of the recommended depth, grain production was higher for the proportions of 50 and $75 \%$ calcium silicate. These results indicate that silicon mitigated water deficit in maize plants grown under water stress. For applications of 100, 130 and $160 \%$ of the recommended irrigation depth, no significant differences in maize production were observed at the different calcium silicate proportions tested. In rice, an increase in grain production has been observed after application of calcium silicate, particularly when the plants were exposed to lower amounts of water available in soil. Thus, the lower the field capacity of soil, the greater the response of plants to silicon (Moro et al. 2015). The $\mathrm{H}_{4} \mathrm{SiO}_{4}$ monomer is the silicon compound present in the liquid phase of soil in the
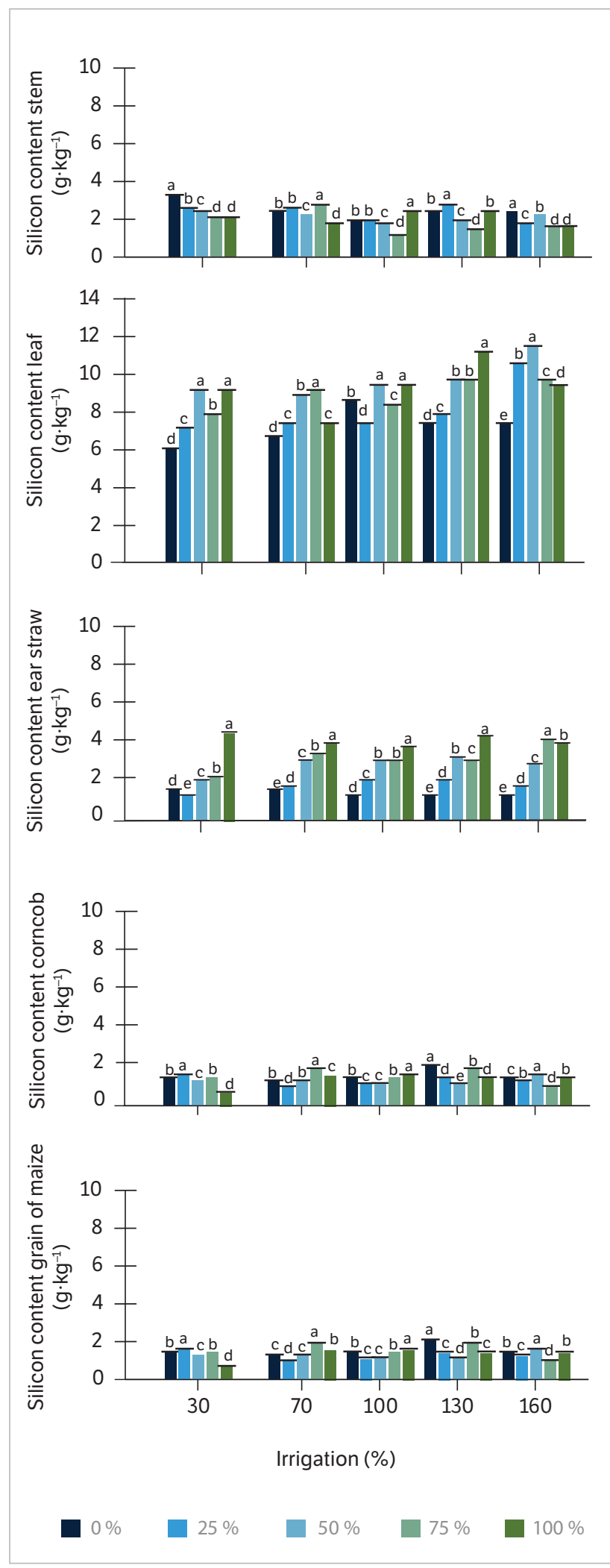

Figure 6. Silicon concentration in the stem (a), leaf (b), ear husks (c), cob (d) and corn grain (e) for the different irrigation levels and proportions of silicate calcium. 


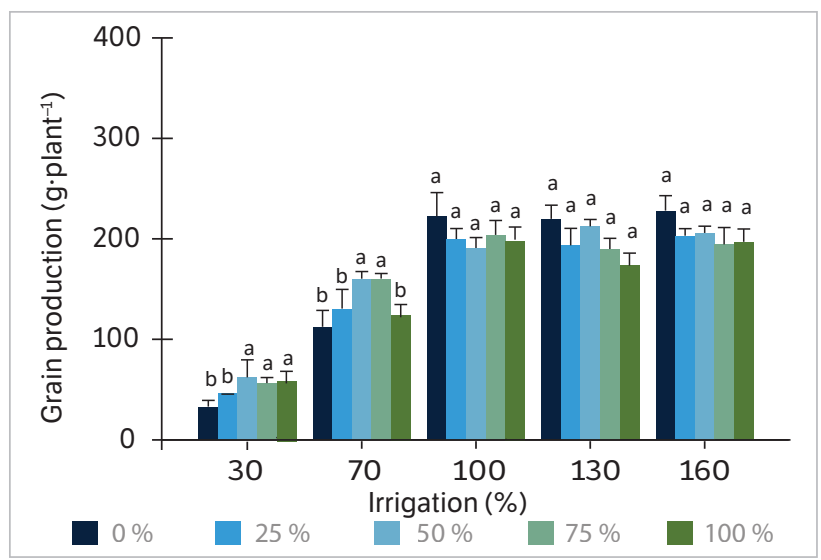

Figure 7. Grain production in maize plants (cv. BR 106) exposed to five corrective associations $(0,25,50,75$, and $100 \%$ of calcium silicate) and five irrigation depths.

$\mathrm{pH}$ range of 4 to 9 (Marschner 1995), which is absorbed by plant roots in a passive or active manner mediated by specific membrane transporters. Many studies have been conducted in an attempt to better adapt crops to regions with limited water resources and to make them more tolerant to acidity (van Raij et al. 1998). However, the yield of species under stress lags behind their production potential, including maize, which is poorly tolerant to water deficit (Silva et al. 1984) and whose cultivation in the semiarid regions of northeastern Brazil is of the utmost importance not only to directly meet the food requirements of the population, but also for the regional agro-industry. The absorption of Si has benefits for crops, including an increase in lodging resistance and in photosynthetic activity. Silicon is a chemical element involved in physical functions that regulate evapotranspiration and is able to form a mechanical barrier against fungal and bacterial invasion of the plant, as well as pest insect attack (Costa et al. 2009). This protective effect is mainly attributed to the deposition of $\mathrm{Si}$ in the form of amorphous silica $\left(\mathrm{SiO}_{2} \cdot \mathrm{nH}_{2} \mathrm{O}\right)$ in the cell wall. The accumulation of silicon in the stomata leads to the formation of a double layer of cuticular silica, which, by reducing transpiration (Datnoff et al. 2001), lowers the water requirements of plants. This can be extremely important for plants growing in tropical soils, where they are subjected to dry spells. Photosynthesis plays an important role in crop production (Wullschleger and Oosterhuis 1990), since grain yield is potentially influenced by the duration of the carbohydrate accumulation rate (Crafts-Brandner and Poneleit 1992). According to Jordan (1983), water deficit conditions can affect the use of carbohydrates basically by altering the efficiency at which photoassimilates are converted for the development of new parts of the plant. Water deficit causes changes in carbohydrate partitioning inside the plant, which results in the development of adaptation and resistance mechanisms by the plants.

\section{CONCLUSION}

Matric potential monitoring confirmed that the irrigation depths employed resulted in different environments for maize plant development during the experiment.

Confirming the hypothesis of the study, it was found that the smaller water depths of maize production were proportional to the increase in calcium silicate dose to the ratio of $50 \%$. These results indicate that silicon mitigated the water deficit in maize plants grown under water stress and increased the xylem water potential.

\section{ACKNOWLEDGEMENTS}

This work was supported through a research grant for D. J. M. by the Coordenação de Aperfeiçoamento de Pessoal de Nível Superior (CAPES, Brasília, Brazil). We also thank the Conselho Nacional de Desenvolvimento Científico e Tecnológico (CNPq, Brasília, Brazil) for financial support.

\section{REFERENCES}

Álvarez V., V. H., Novais, R. F., Dias, L. E. and Oliveira, J. A. (2000). Determinação e uso do fósforo remanescente. Sociedade Brasileira de Ciência do Solo, 25, 27-33.

Anne, P. (1945). Sur le dosage rapide du carbone organique des sols. Annales Agronomiques, 2, 161-172.
Asch, F., Dingkuhn, M. and Dorffing, K. (2000). Salinity increases $\mathrm{CO}_{2}$ assimilation but reduces growth in field-grown, irrigated rice. Plant and Soil, 218, 1. http://dx.doi.org/10.1023/A:1014953504021. Assad, E. and Pinto, H.S. (2008). Aquecimento global ea nova geografia da produção agrícola no Brasil. São Paulo: Embrapa; Cepagri. 
Boletim Agrometeorológico Semanal (2014) Milho; [accessed 2014 Feb 4]. http://www.cbiagro.com.br/Arquivos/BoletimSemanal/57_ Boletim_Semanal_03022014.pdf

Bortolon, L. and Gianello, C. (2010). Simultaneous multielement extraction with the Mehlich-1 solution for Southern Brazilian soils determined by ICP-OES and the effects on the nutrients recommendations to crops. Revista Brasileira de Ciência do Solo, 34,125-132. http://dx.doi.org/10.1590/S0100-06832010000100013.

Costa, R. R., Moraes, J. C. and Costa, R. R. (2009). Interação silício-imidacloprid no comportamento biológico e alimentar de Schizaphis graminum (Rond.) (Hemiptera: Aphididae) em plantas de trigo. Ciência e Agrotecnologia, 33, 455-460. http://dx.doi. org/10.1590/S1413-70542009000200014.

Crafts-Brandner, S. J. and Poneleit, C. G. (1992). Selection for seed growth characteristics: effect on leaf senescence in maize. Crop Science, 32, 127-131. http://dx.doi.org/10.2135/ cropsci1992.0011183X003200010028x.

Cuartero, J. and Fernández-Muñoz, R. (1998). Tomato and salinity. Scientia Horticulturae, 78, 83-125. http://dx.doi.org/10.1016/ S0304-4238(98)00191-5.

Datnoff, L. E., Snyder, G. H. and Korndörfer, G. H. (2001). Silicon on agriculture. Amsterdam: Elsevier Science.

Day, P. R. (1965). Particle fractionation and particle-size analysis. In C. A. Black (Ed.), Methods of soil analysis. Part 1 (p. 541-566). Madison: American Society of Agronomy.

Dexter, A. R. (2004). Soil physical quality. Part I. Theory, effects of soil texture, density, and organic matter, and effects on root growth. Geoderma, 120, 201-214. http://dx.doi.org/10.1016/j. geoderma.2003.09.004.

Durães, F. O. M., Magalhães, P. C., Oliveira, A. C., Santos, M. X., Gama, E. E. G. and Guimarães, C. T. (2002). Combining ability of tropical maize inbred lines under drought stress conditions. Crop Breeding and Applied Biotechnology, 2, 291-298.

Empresa Brasileira de Pesquisa Agropecuária. Centro Nacional de Pesquisa de Solos (2006). Sistema Brasileiro de Classificação de solos. 2. ed. Brasília: Embrapa-SPI; Rio de Janeiro: Embrapa Solos.

Empresa Brasileira de Pesquisa Agropecuária. Centro Nacional de Pesquisa de Solos (2013). Cultivares de milho BR 106. Brasília: Embrapa; CNPMS.

Giehl, R. F. H. and Wirén, N. (2014). Root nutrient foraging. Plant Physiology, 166, 509-517. http://dx.doi.org/10.1104/pp.114.245225.
Grattan, S. R. and Grieve, C. M. (1999). Salinity-mineral nutrient relations in horticultural crops. Scientia Horticulturae, 78, 127-157. http://dx.doi.org/10.1016/S0304-4238(98)00192-7.

Hashemi, A., Abdolzadeh, A. and Sadeghipour, H. R. (2010). Beneficial effects of silicon nutrition in alleviating salinity stress in hydroponically grown canola, Brassica napus L., plants. Soil Science and Plant Nutrition, 56, 244-253. http://dx.doi. org/10.1111/j.1747-0765.2009.00443.x.

Hodson, M. J., White, P. J., Mead, A. and Broadley, M. R. (2005). Phylogenetic variation in the silicon composition of plants. Annals of Botany, 96, 1027-1046. http://dx.doi.org/10.1093/ aob/mci255.

Instituto Brasileiro de Geografia e Estatística (2010). Sistema IBGE de recuperação automática; [accessed 2010 Feb 25]. http://www. sidra.ibge.gov.br

Jordan, W. R. (1983). Whole plant response to water deficits: an overview. In H. M. Taylor, W. R. Jordan and T. R. Sinclair (Eds.), Limitations to efficient water use in crop production (p. 289-317). Madison: ASA; CSSA; SSA.

Klar, A. E. and Porto, C. A. L. (1998). Efeitos do déficit hídrico em parâmetros fisiológicos de folhas de sorgo (Sorghum bicolor L.). Brazilian Journal of Irrigation and Drainage, 3, 151-163.

Lutts, S., Bouharmont, J. and Kinet, J. M. (1999). Physiological characterisation of salt-resistant rice (Oryza sativa L.) somaclones. Australian Journal of Botany, 47, 835-849. http://dx.doi.org/10.1071/ BT97074.

Ma, J. F. (2004). Role of silicon in enhancing the resistance of plants to biotic and abiotic stresses. Soil Science and Plant Nutrition, 50, 11-18. http://dx.doi.org/10.1080/00380768.200 4.10408447.

Ma, J. F. and Takahashi, E. (2002). Soil, fertilizer, and plant silicon research in Japan. Amsterdam: Elsevier Science.

Malavolta, E., Vitti, G. C. and Oliveira, S. A. (1997). Avaliação do estado nutricional das plantas: princípios e aplicações. 2. ed. Piracicaba: Potafos.

Marschner, P. (1995). Marschner's mineral nutrition of higher plants. 2. ed. London: Academic Press.

Moro, A. L., Broetto, F. and Moro, E. (2015). Relação hídrica e teor de clorofila em dois cultivares de arroz submetido à deficiência hídrica e adubação silicatada. Irriga, 20, 570-586. 
Novais R. F., Neves, J. C. L. and Barros, N. F. (1991). Experiment in controlled environment. In Research methods in soil fertility. Brasília: Embrapa.

Olsen, S. R. and Watanabe, F. S. (1957). A method to determine a phosphorus adsorption maximum of soils as measured by the Langmuir Isotherm. Soil Science Society of America Journal, 21, 144149. http://dx.doi.org/10.2136/sssaj1957.03615995002100020004x.

Patakas, A., Nikolaou, N., Ziozioiu, E., Radoglou, K. and Noitsakis, B. (2002). The role of organic solute and ion accumulation in osmotic adjustment in drought-stressed grapevines. Plant Science, 163, 361-367. http://dx.doi.org/10.1016/S0168-9452(02)00140-1.

Resende, M., França, G. E. and Couto, L. (2008). A cultura do milho: viabilidade e manejo da irrigação. Sete Lagoas: Embrapa Milho e Sorgo.

Richards, L. A. (1954). Diagnoses and improvement of saline and alkali soils. Washington: US Department of Agriculture. (USDA Agricultural Handbook, 60).

Rockström, J. and Falkenmark, M. (2000). Semiarid crop production from a hydrological perspective: gap between potential and actual yields. Critical Reviews in Plant Sciences, 19, 319-346. http://dx.doi. org/10.1080/07352680091139259.

Salah, H. B. H. and Tardieu, F. (1997). Control of leaf expansion rate of droughted maize plants under fluctuating evaporative demand (a superposition of hydraulic and chemical messages?). Plant Physiology, 114, 893-900. http://dx.doi.org/10.1104/pp.114.3.893.

SAS Institute (1996). SAS/STAT user's guide, Version 6.12. Cary: SAS Institute.

Scholander, P. F., Hammel, H. T., Hemmingsen, E. A., and Bradstreet, E. D. (1964). Hydrostatic pressure and osmotic potential in leaves of mangroves and some other plants. Proceedings of the National Academy of Sciences USA, 52, 119-125.
Silva, J. B. C., Novais, R. F. and Sediyama, C. S. (1984). Identificação de genótipos de sorgo tolerantes à toxicidade de alumínio. Revista Brasileira de Ciência do Solo, 7, 77-83.

Steel, R. G. D., Torrie, J. H. and Dickey, D. A. (2006). Principles and procedures of statistics: a biometrical approach. 3. ed. Moorpark: Academic Internet Publishers.

Stenseth, N. (2002). Ecological effects of climate fluctuations. Sciences Compass Review, 297, 23-31.

Takahashi, E., Ma, J. F. and Miyake, Y. (1990). The possibility of silicon as an essential element for higher plants. Comments on Agricultural and Food Chemistry, 2, 99-122.

Thomas, G. W. (1982). Exchangeable cations. In A. L. Page, R. H. Miller and D. R. Keeney (Eds.), Methods of soil analysis. Part 2 (p.159-165). Madison: American Society of Agronomy.

Turner, N. C. (1988). Measurement of plant water status by the pressure chamber technique. Irrigation Science, 9, 289-308. http:// dx.doi.org/10.1007/BF00296704.

Van Genuchten, M. (1980). A closed-form equation for predicting the hydraulic conductivity of unsaturated soils. Soil Science Society of America Journal, 44, 892-898. http:// dx.doi.org/10.2136/sssaj1980.03615995004400050002x. Van Raij, B., Furlani, P. R., Quaggio, J. A. and Pettinelli Junior, A. (1998). Gesso na produção de cultivares de milho com tolerância diferencial a alumínio em três níveis de calagem. Revista Brasileira de Ciência do Solo, 22, 101-108. http://dx.doi.org/10.1590/ s0100-06831998000100014.

Wullschleger, S. D. and Oosterhuis, D. M. (1990). Photosynthetic carbon production and use by developing cotton leaves and bolls. Crop Science, 30, 1259-1264. http://dx.doi.org/10.2135/ cropsci1990.0011183X003000060021x. 